\title{
Aandeelhouderswaarde en jaarrekening
}

\section{Martin Hoogendoorn}

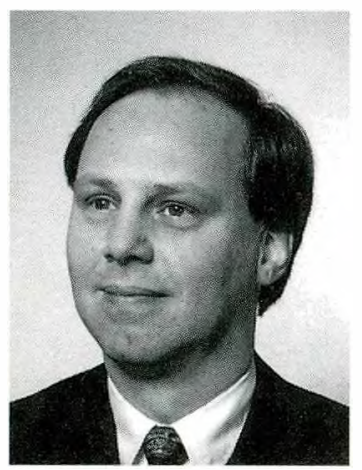

\section{Volgens algemeen} aanvaarde opvattingen is een jaarrekening primair retrospectief gericht en geeft het eigen vermogen op de balans niet de waarde van de onderneming weer. De waarde van de onderneming, de aandeelhouderswaarde

of 'shareholder value', is toekomstgericht: deze waarde is gelijk aan de geschatte contante waarde ran de toekomstige kasstromen. Er is derhalve sprake van een kloof tussen het eigen vermogen in de jaarrekening en de aandeelhouderswaarde. Een kloof die merkwaardige gevolgen heeft.

In een recent artikel van Van Hulsen (1996) is ran 149 Nederlandse beursfondsen het verschil vastgesteld tussen het eigen vermogen volgens de balans op 31 december 1993 en de beurswaarde van de uitstaande aandelen op die datum. It stel hierbij heurswaarde en aandeelhouderswaarde voor het gemak even aan elkaar gelijk. Ik kom daar zo op terug. Bij 35 ondernemingen was de beurswaarde lager dan het eigen vermogen. Het grootste negatieve verschil was de beurswaarde van Phoenix Beheer, die slechts $46 \%$ bedroeg van het gerapporteerde eigen vermogen. Aan de andere kant was bij 44 ondernemingen de beurswaarde

Prof. Dr. M.N. Hoogendoorn is directeur bij Moret Ernst \& Young Accountants, hoogleraar Externe Verslaggeving Universiteit van Amsterdam, onderzoeker Limperg Instituut en lid controleursdelegatie Raad voor de Jaarverslaggeving. meer dan twee maal het eigen vermogen, met een maximum van maar liefst $1435 \%$ (Wolters Kluwer). Het eigen vermogen op een balans is zelfs niet een indicatie van de andeelhouderswarde: de aandeelhouderswaarde kan minder dan de helft zijn, maar ook meer dan 14 keer zo hoog.

Waardoor ontstaan deze grote verschillen? De belangrijkste oorzaak van een hogere beurswaarde is zonder twijfel de directe afboeking van gekochte goodwill van het eigen vermogen. In zijn proefschrift heeft Huijgen (1996) nog onlangs aangetoond dat aandeelhouders wel degelijk waarde toekennen aan goodwill, ook al wordt deze niet geactiveerd. Op zich is dat niet verrassend. verrassender zou het tegendeel zijn, maur het geeft nog maar eens aan dat betaling voor goodwill ook door aandeelhouders als een voor activering vatbare investering wordt gezien. Wolters Kluwer is inmiddels overgegaan tot het activeren van goodwill. Echter, per 31 december 1996, na activering van de goodwill, is de beur'swaarde nog altijd $1306 \%$ van het eigen vermogen. Waardoor komt dat? Voor Wolters-Kluwer geldt in het bijzonder dat niet alle in het verleden betaalde goodwill op de balans is opgenomen. Voor ondernemingen in het algemeen kunnen afzonderlijk identificeerbare maar niet opgenomen immateriële activa (uitgaverechten, merken, know how') een helangrijke oorzaak zijn. En er kunnen stille reserves in de materiële vaste activa zitten doordat de actuele waarde van gebouwen en terreinen significant hoger is dan de op historische uitgaafprijs gebaseerde boekwaarde. Financiële instrumenten zijn mogelijk niet op marktwaarde gewaardeerd. En wellicht is de omvang van de voorzieningen aan de hoge kant en wordt door de markt een significant lager niveau van mogelijke verplichtingen en risico's ingeschat. 
Kenmerk van deze verschillen is dat zij binnen het systeem van de aanvaardbare grondslagen van de jaarrekening oploshaar zijn. Goodwill kan worden geactiveerd, immateriële activa kunnen worden opgenomen, gebouwen en terreinen kunnen worden geherwaardeerd, financiële instrumenten kunnen tegen marktwaarde worden opgenomen, en voorzieningen kunnen worden verlaagd. Gevolg: het gerapporteerde eigen vermogen komt meer in de buurt van de aandeelhouderswaarde. De internationale regels van het IASC gaan sterk in de richting van het verminderen van de verschillen tussen eigen vermogen en aandeelhouderswaarde (Hoogendoorn, 1996) en dit zal zonder twijfel gevolgen hebhen voor de regelgeving in Nederland.

Maar er zijn ook enkele vooralsnog onoverbrugbare verschillen. De wettelijke regeling in Nederland is terughoudend inzake het activeren van zelf-ontwikkelde (afzonderlijk identificeerbare) immateriële activa. Ook is het waarderen boven verkrijgingsprijs van gekochte immateriële activa wettelijk niet toegestaan. En ten slotte is er de missing link, het sluitstuk, de zelf-ontwikkelde (niet afzonderlijke verhandelbare) goodwill. De zelf-ontwikkelde goodwill is per definitie het verschil tussen de aandeelhouderswaarde van de onderneming en het eigen vermogen op basis van waardering van afzonderlijke activa en passiva. Bij activering van de zelf-ontwikkelde goodwill (of indien van toepassing passivering van de door eigen toedoen ontstane badwill) worden het eigen vermogen en de aandeelhouderswaarde aan elkaar gelijk. De functie van de jaarrekening is dan niet meer het bepalen van het eigen vermogen, maar het aangeven uit welke componenten het eigen vermogen is opgebouwd. In de toelichting kan dan informatie worden gegeven over de schattingen die zijn gehanteerd bij de waardering van de verschillende componenten en de onzekerheden en risico's die hierbij aanwezig zijn.

Hierbij doet zich nog de vraag voor of de aandeelhouderswaarde gelijk kan worden gesteld aan de beurswaarde op balansdatum. In elk geval is de beurswaarde een objectieve indicatie van de ondernemingswaarde. Dit neemt niet weg dat bij overnames veelal een hoger bedrag per aandeel wordt geboden dan de beurskoers. De koers past zich na een overnamebod snel aan en in die zin kan de markt efficiënt worden genoemd. Onlangs deed zich ook het tegenovergestelde voor: het bod op de aandelen MoGen International was minder dan de helft van de beurskoers (en ook nu paste de beurskoers zich direct aan). Voorts is van belang dat de waarde van een onderneming niet in dezelfde mate fluctueert als de beurskoersen. Als alternatief voor jaarlijkse waardebepaling kan dan ook w'orden gedacht aan inschakeling van onafhankelijke taxateurs, maar al te grote afwijkingen tussen aandeelhouderswaarde en beurswaarde zullen zich redelijkerwijze niet voor kunnen doen.

Is het wenselijk de huidige kloof tussen aandeelhoudersw'aarde en eigen vermogen in de jaarrekening te dichten? Ik vind van wel. Dit past geheel bij de door de Commissie Peters ingezette lijn: adequate verantwoording naar aandeelhouders is een essentieel aspect van Corporate Governance en een adequate verantwoording betreft in elk geval inzicht in de omvang en ontwikkeling van de aandeelhouderswaarde. Op korte termijn houdt dit in een beroep op het opheffen van de overbrughare verschillen, hetgeen zoals gezegd aansluit op de internationale harmonisatie-inspanningen van het IASC. Eveneens op korte termijn houdt dit in dat in de toelichting van de jaarrekening een verklaring wordt gegeven voor de verschillen tussen de beurswaarde en het eigen vermogen volgens de halans, zowel bij een hogere als bij een lagere beurswaarde. En op langere termijn zullen de laatste bastions van retrospectieve verslaggeving moeten worden geslecht. Zo rond het jaar 2000 verwacht ik in Nederland de eerste additionele overzichten waarin zelf-ontwikkelde goodwill is geactiveerd. Maar het zal denk ik nog wel zo'n 20 jaar duren voordat de wet-en regelgeving opname in de primaire geconsolideerde jaarrekening toestaat. Pas dan kan de kloof tussen het eigen vermogen in de jaarrekening en de aandeelhouderswaarde worden gedicht.

\section{I T E R A T U U R}

Hoogendoorn, M.N., (1996), Dynamics in financial accounting: de ontwikkeling van retrospectieve naar prospectieve financiële verslaggeving, FMA Kroniek, Samsom, pp. 51-65.

Hulsen, P.H.A. van, (1996), Beurswaarde en externe verslaggeving, TBA, mei, pp. 181-192.

Huijgen, C.A., (1996), Valuation of purchased goodwill, Labyrinth Publication. 